\title{
BOLTING, A VEGETATIVE VARIATION IN THE POTATO
}

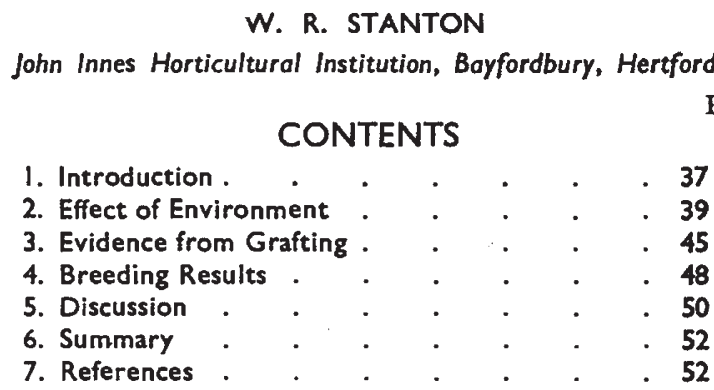

\section{INTRODUCTION}

Pотато varieties are conveniently classified according to the time the tubers mature and the crop is ready for harvesting as early $\left(\mathrm{E}_{1}\right)$, second early $\left(\mathrm{E}_{2}\right)$ maincrop $\left(\mathrm{E}_{3}\right)$ and late varieties $\left(\mathrm{E}_{4}\right)$. In approximately 80 per cent. of the early varieties $\left(E_{1}, E_{2}\right)$ but in only 20 per cent. of the main crop $\left(E_{3}\right)$ and apparently never in the later varieties abnormal plants may be found. These differ from the type in several respects. They have taller haulms, flower abundantly, and continue to grow when the normal crop is mature. The tubers they produce are coarser, deeper-eyed and are borne on longer stolons than the normal plants, from which the new types arise as vegetative sports. They vary greatly with environmental conditions and lead to much speculation as to the cause and origin of these plants.

This aberrant condition in the potato commonly called "Bolting" has long been recognised as a trouble of the growers of potato tubers for " seed," as they have constantly to rogue their stocks. A search for the cause of the aberration started about 1920 and from 1927 until quite recently the condition has been classified with the virus diseases (Folsom, 1927 ; McIntosh, 1931; Murphy, 1932 ; Hansen, 1936). Prior to 1927 it had been classified as a degenerative change of unknown origin (Anderson, 1925; Salaman, 1926). In the United States an aberration called "Giant Hill" has been shown to be identical with bolting by Murphy and McKay (1932).

\section{Photoperiodic reaction}

The study of the photoperiodic reaction of the South American potatoes began with the work of Hackbarth (1935) and has been followed by the extensive work on the Empire Potato Collection made by Driver and Hawkes (1943). These studies showed a similarity 
between the normal-bolter change in our cultivated varieties and the change in appearance of short-day adapted Solanum andigenum clones when grown under long-day conditions. That the bolter behaves as a short-day adapted potato has been subsequently demonstrated by Hawkes (1947).

\section{Occurrence}

How bolting arises and how it is inherited are still uncertain. In vegetative propagation the condition can apparently exist for many years (Davidson, I937) and, according to Yarwood (1946), it is possible to retain the identity of a number of "Giant Hill" strains from year to year. However such differences have not been precisely recorded in this country, although growers commonly speak of semi- and super-bolter conditions. The frequency with which new bolters may arise somatically may be as high as I per cent., so Dr Black tells me, but accurate information is still lacking on this point.

Preliminary studies on the inheritance of the condition have yielded unsatisfactory results (Carson and Howard, 1944; Revell, 1947), the difficulty in scoring being due to the wide variation in the appearance of the bolter itself and also the progeny.

Degrees of bolting are sometimes mentioned (Davidson, I937; Scottish Department Agriculture, 1944). They have been called semi-bolter, full bolter and super-bolter. Semi-bolters are often so little differentiated from the normal that reports about them are unreliable. Super-bolters are apparently rare; occurring with a frequency of the order of one-hundredth of that of the equivalent bolters. The three conditions will be called in this paper semi-bolter $\mathrm{B}-$, full bolter $\mathrm{B}$ and super-bolter $\mathrm{B}+$. Experiments have been conducted only on the bolter (B).

The relation, in terms of lateness of maturity, of the various types of bolter is shown in fig. I. Examples are given of the behaviour of varietics from each of the groups $E_{1}, E_{2}$ and $E_{3}$.

The differences between the normal and bolter (B) conditions may be summarised as follows and the " time of planting experiment" subsequently described has shown the relative value of some of the following characters for general application in the scoring of field plots.

\section{Flowering}

Bolters flower abundantly, more initials being produced and more flower buds reaching maturity. Flowers appear earlier and more often and bear fruit on normally unfruitful varieties.

\section{Haulm growth}

The haulm is taller and more robust. The leaflets are thicker and, with high nitrogen nutrition, puckered due to interveinal growth. 


\section{Tuber formation}

This is delayed so that an early variety $\left(E_{1}\right.$ or $\left.E_{2}\right)$ is in effect converted into maincrop or late variety $\left(E_{3}\right.$ or $\left.E_{4}\right)$. The tubers, relatively numerous, are borne on longer stolons and may show secondary growth.

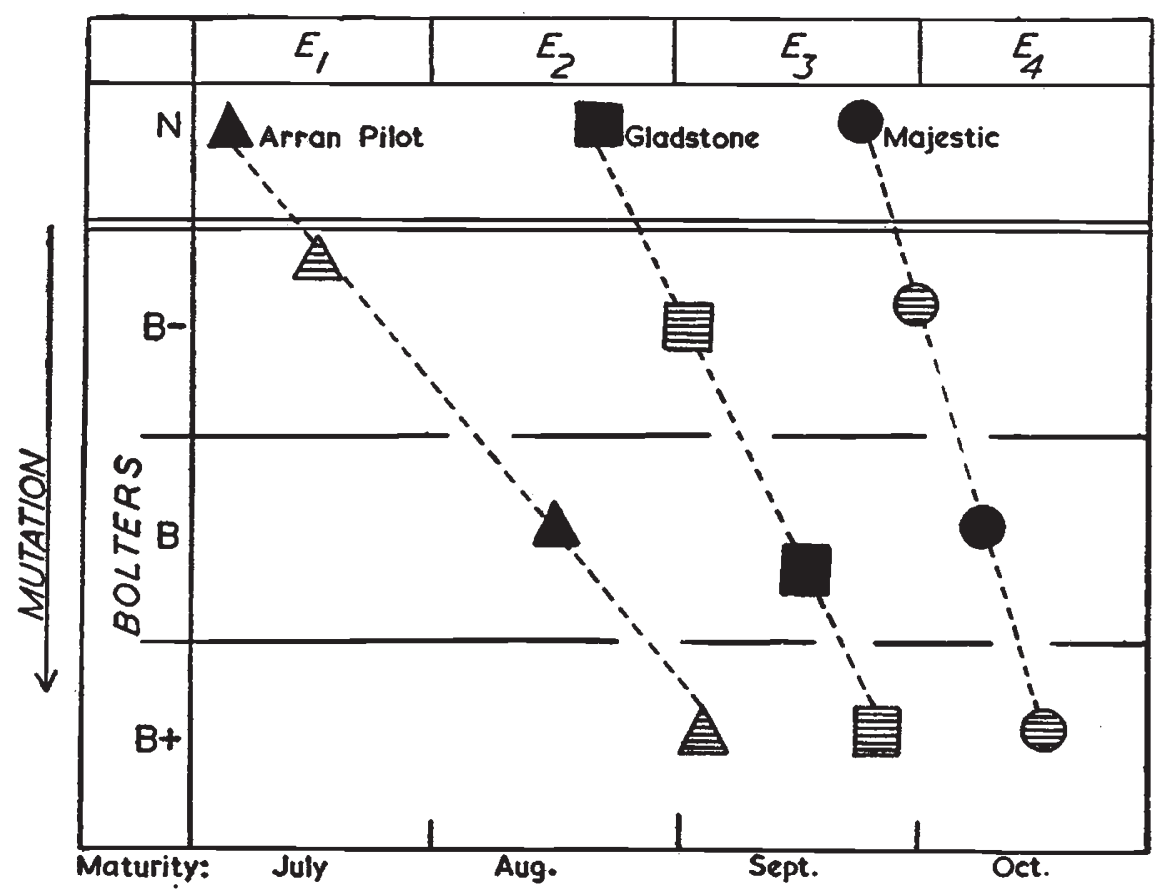

FIG. I.-Diagram showing the change of maturity in three varieties accompanying the change Normal-Bolter.

$\mathrm{E}_{1}, \mathrm{E}_{2}, \mathrm{E}_{3}, \mathrm{E}_{4}$, Classification of maturity. $\mathrm{N}=$ Normal. $\mathrm{B}-=$ semi-bolter ; $\mathrm{B}=$ bolter ; $\mathrm{B}+=$ super-bolter. (For details of the differences between these three types see text.) Note that the "maturity-shift," towards later maturity, changes according to the time of maturing of the original variety. The greatest maturity-shift occurs with early varieties.

The location of points on the bars $\mathrm{B}-$ and $\mathrm{B}+$ are tentative. The difference in the time of maturing between the $\mathrm{N}$ and $\mathrm{B}-$ is hard to detect.

\section{Tuber shape}

Tubers of bolters are rougher skinned, on the average less regular in shape, and with deeper eyes. In kidney shaped varieties the tubers may become spindle shaped (see plate I).

\section{EFFECT OF ENVIRONMENT}

To study the variation of the bolter (B) condition, a series of plots containing normals and bolters was laid out in the spring and summer 
of 1948 . The following varieties, kindly supplied by Dr W. Black of the Scottish Plant Breeding Station, were used :-

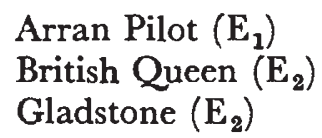

\author{
Normal and Bolter (B) \\ Normal \\ Normal and Bolter (B)
}

Plots of 15 tubers of each of the above were planted at three-weekly

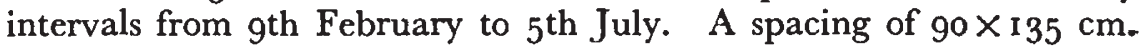
was necessary to allow for detailed excavation. The tubers were planted without being chitted, i.e. exposed before planting to full sunlight on benches or trays in a greenhouse for four weeks or more, after having been stored in trays in a basement with a low temperature $\left(5-8^{\circ} \mathrm{C}\right.$. $)$. After the end of March, remaining tubers were stored in a refrigerator at $5^{\circ} \mathrm{C}$. The tubers were planted with the rose-end Io $\mathrm{cm}$. below ground level with the exception of the last planting which was started in pots in a closed frame. Enough Gladstone bolters were obtainable for only one plot of fifteen tubers. These were planted on I2th April.

A photoperiodic treatment was given to the two plot series planted on $3^{\text {rd }}$ May and $15^{\text {th }}$ June. The first six plants of each of these plots were screened from the time of emergence so that they would receive the same length of day as those planted on 22nd March. The diurnal duration of covering was changed at weekly intervals to give an increasing day-length corresponding to the week by week natural increases in day length after 22nd March.

As previously mentioned, several characters of a variety are altered by the change from normal to bolter (B). Two characters, haulm height and stolon length were recorded in detail, and as the full normal-bolter comparison was possible only for the variety Arran Pilot $\left(E_{1}\right)$, observations on this comparison are confined to this variety.

Haulm height was measured at 10-day intervals from the time of mean emergence to the maturity of the normal plants of a particular planting time. Except for the last series (5 th July) which were lifted immature, lifting of normals and bolters took place at the time of maturity of the normals (see figs. $2 a$ and $2 b$, and table 1 ).

The form of the growth curve is shown by the graph (fig. 2a) of the mean haulm heights of the different plots of the 3 rd May planting from emergence to maturity of the normal plants. It will be seen that the slope of the curves for normal and bolters is the same. The characteristic difference between them being the greater length arising from longer duration of growth of the bolter curve as compared with the normal.

This difference is shown in fig. $2 b$ for the various planting times. This graph gives the mean maximum height of the normals, with 
their different planting dates, the mean maximum height of the corresponding bolter plots at the same time, and the difference between them.

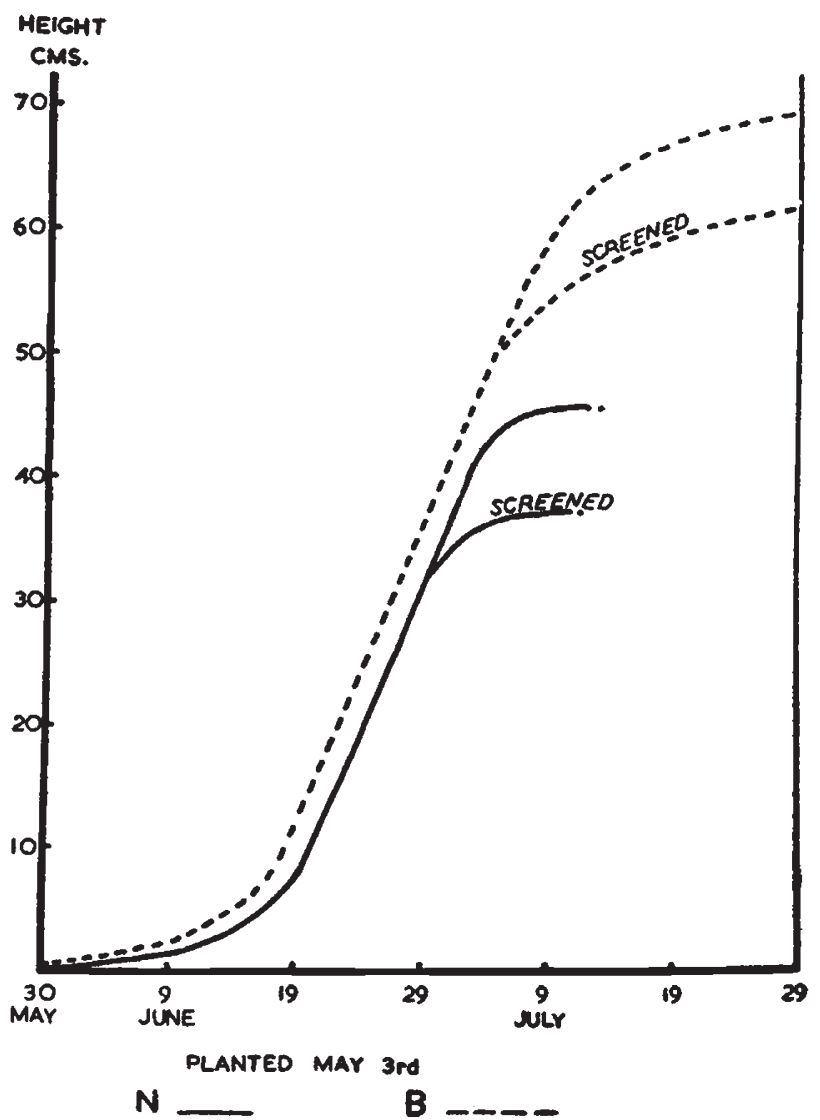

Frg. 2a.-Increase in height of plants from mean ground level (plot mean) measured at ro-day intervals. The height taken was to the apex of the tallest haulm.

The plants were lifted by excavating a trench along each side of the row and teasing out the soil between the stolons. All stolons bearing tubers of over lo gms. were measured and fig. 3 shows the variation in the mean stolon length according to the time of planting. Mean stolon length is increased with lateness of planting, but the stolons of bolters are longer than those of the corresponding normals. Screening of late planted tubers gives plants with short stolons as at early plantings. The inversion of the relative stolon lengths for the 12th April planting was found to be due to frost damage. Bolters appear to be slightly more resistant than normals to frost and, as a result, the stolons were coming from the primary shoots of the bolters, but only from laterals on the normals. Thus the stolons of the normals 


\section{ARRAN PILOT $\left(E_{1}\right)$. SUMMARY OF GROWTH CURVES FOR THE DIFFERENT PLANTING DATES.}

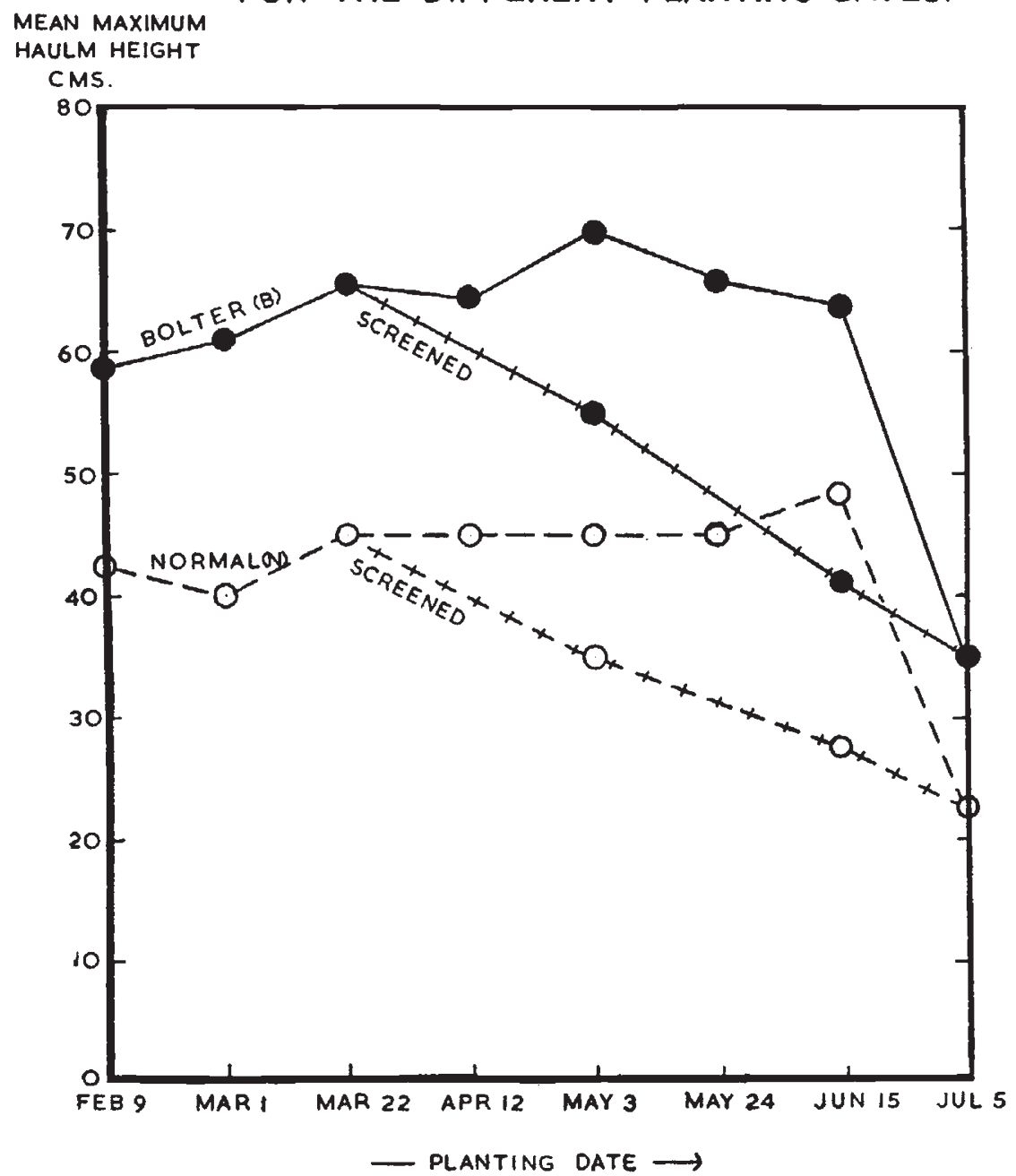

FxG. 2b. - The mean maximum haulm height is shown for normals (N) at the time of their maturity and the heights of bolters (B) at the same time.

\section{TABLE I}

Length of growing period of Arran Pilot $(\mathcal{N})$ when planted at different times

\begin{tabular}{l|c|c|c|c|c|c|c|c}
\hline Planted & Feb. 9 & Mar. 1 & Mar. 22 & Apr. 12 & May 3 & May 24 & June 15 & .July 5 \\
Matured (lifting time) & July 25 & Aug. 3 & Aug. 12 & Aug. 20 & Aug. 26 & Aug. 30 & Sep. 14 & Sep. 23* \\
Growing period (days) & J66 & 156 & I43 & I30 & 1 15 & $9^{8}$ & $9^{1}$ & $\ldots$ \\
\hline
\end{tabular}

* Lifted immature. 


\section{EFFECT OF PLANTING TIME ON STOLON LENGTH}

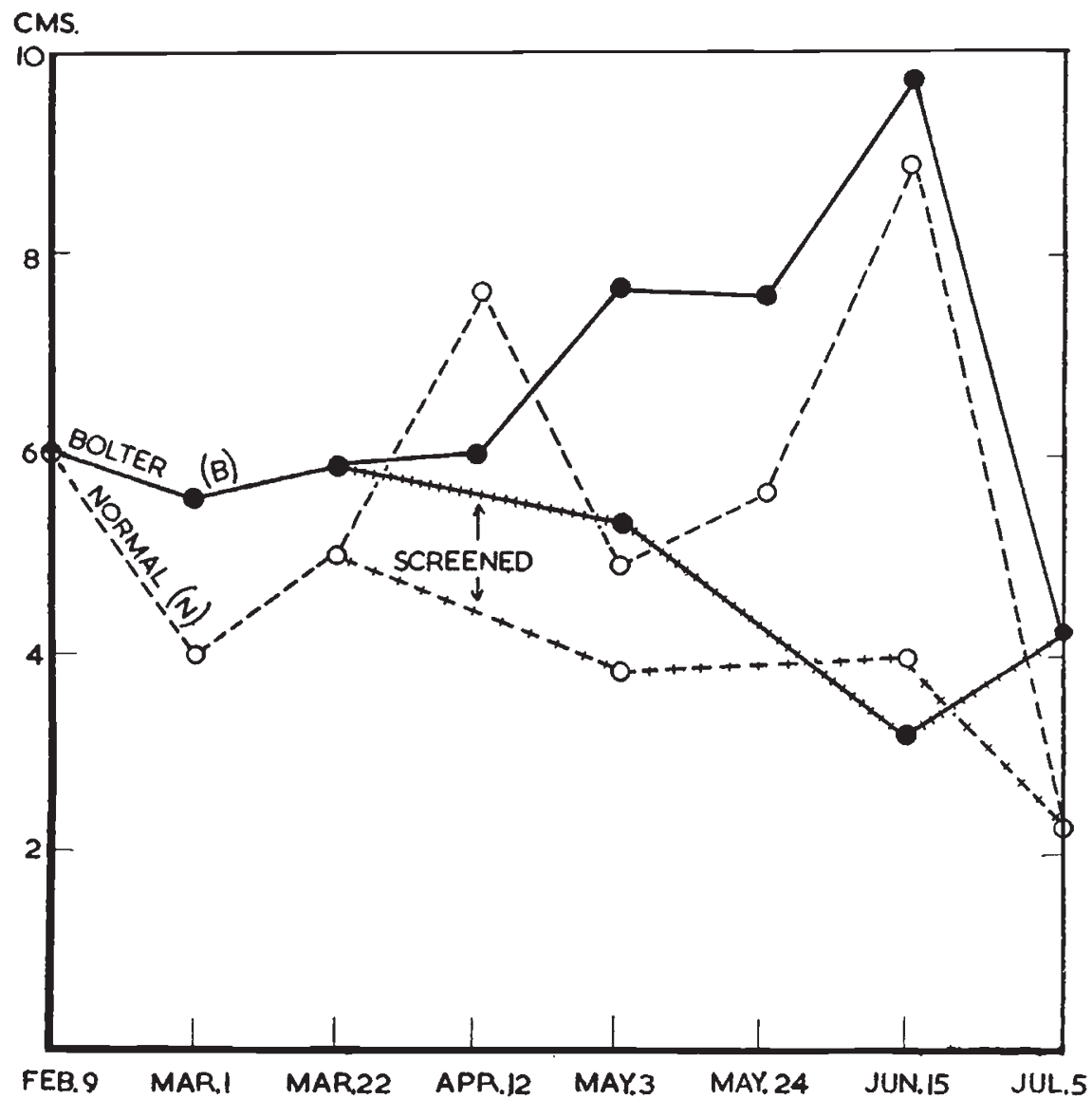

Fig. 3.-Variation in the mean length of stolons with planting time. Mean = plot mean of all stolons bearing tubers of over 10 gms. weight. (For details of screening see text.) Data on screening is available for the May 3 rd and June 22nd series. The normal (N) screened and bolter (B) screened lines show the effect of the lengthening photoperiod which is received by the March 22 nd series. Lifting time is as on fig. $2 b$ for the various planting times.

would be produced later and therefore under longer days. At earlier planting dates the stolons came from laterals on both normals and bolters.

\section{Secondary characters}

(a) Flowering.- The appearance of some plants with flowers in a crop is often the earliest indication of the presence of abnormal plants, but it is not a satisfactory indication, for flower production is under the control of several environmental factors. In Arran Pilot, flower 
production is extremely poor and on 23 rd June 1948 , a scoring gave the results shown in fig. 4 .

The number of open flowers is, for all three planting times, less than one per plant and it is impossible to classify individual plants using this character, although the mean difference is highly significant.
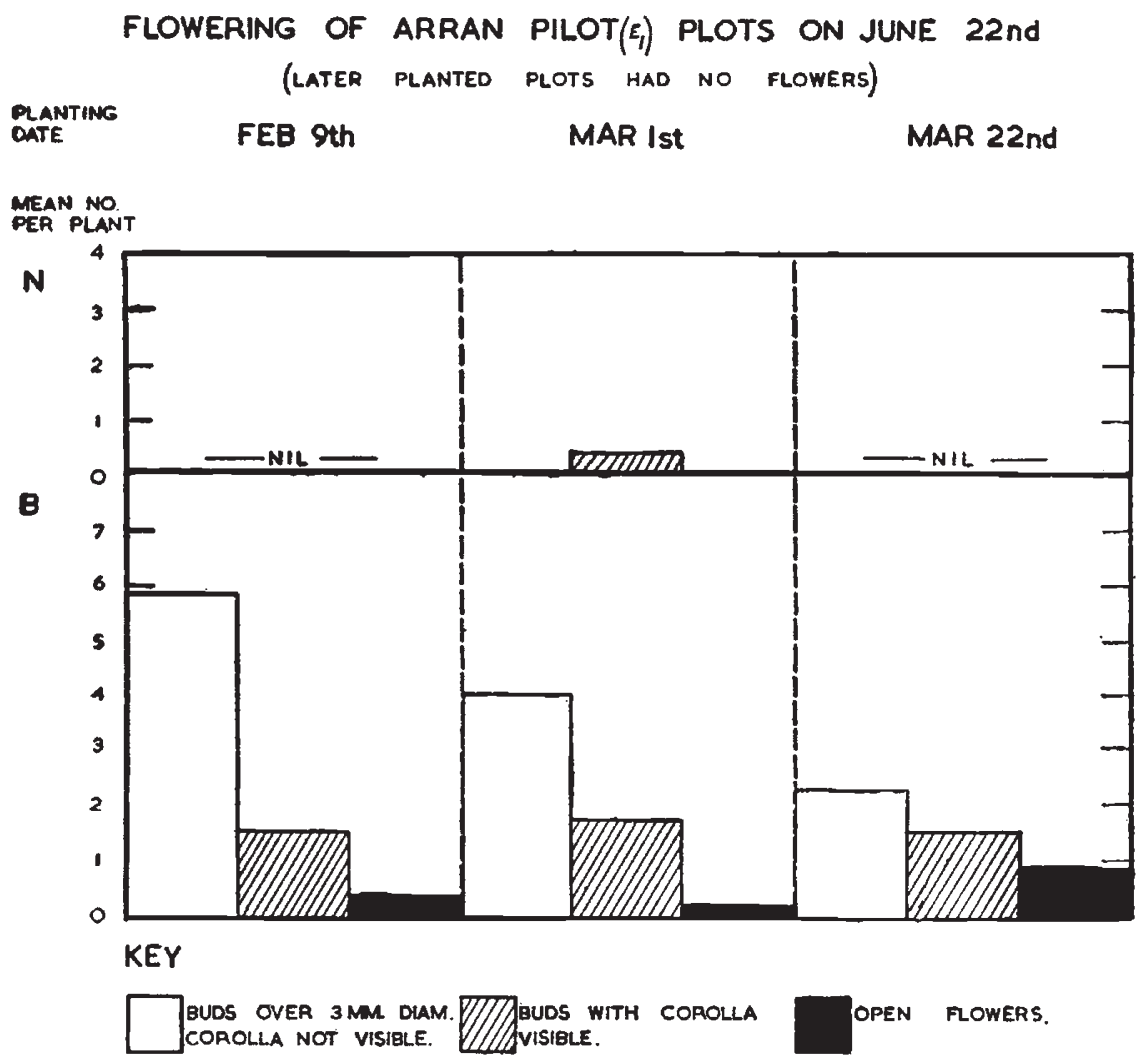

Fig. 4.-Histograms of mean flower production per plant on the plots of Arran Pilot $\left(\mathrm{E}_{1}\right)$ showing flowers on 22nd June. Flowering was at its peak at this time and none of the other plots of this variety flowered at all.

(b) Foliage.-In the Gladstone series again, it was noticed that the bolters showed downward curling of the leaf margin and interveinal crinkling. Samples were sent to $\mathrm{Dr} \mathrm{K}$. M. Smith, Cambridge, to test for freedom from virus and only 3 of the normals and 3 bolters gave a positive test for potato virus $\mathrm{X}$. There was no difference in the appearance of the foliage of the infected bolters and the virusfree bolters, all of which showed the leaf curling not present in the normal.

(c) Storage.-It was noted that the bolter (B) tubers used for late planting, of both Arran Pilot $\left(E_{1}\right)$ and Gladstone $\left(E_{2}\right)$ were firmer 
than those of the normals. This is probably due to a delayed climacteric, but the observations of Yarwood (1946) on reduced storage losses with bolters from fungal attack are also confirmed.

\section{Conclusions}

The growth characteristics demonstrated in the preceding graphs in this section were chosen as exhibiting the most clearly recognisable differences between the bolter and the normal condition. From the small height difference over the period of rapid growth in the curve (fig. I) and from the inversion of the relative mean stolon lengths (12th April, fig. 3) it may be seen that single scorings for presence of bolters may give untrue results. Stolon length shows a significant difference at mid-season planting, but late-planted normals approach bolters in their expression of this character, in that the stolons of normals formed under midsummer conditions ( $15^{\text {th }}$ June planting) lengthen almost as much as bolter stolons.

For plantings of tubers before 22nd March (Early planting), scoring may be possible on difference in flowering. This was discrete in Arran Pilot but not so in Gladstone. At all times of planting, however, there is a difference in duration of growth, and early planting does not obscure this character. Behaviour under conditions of increasing day-length differs therefore from that of permanent short day treatment. Under the latter condition the duration of growth of bolters approaches that of normals (Hawkes, I947).

Covering of the plants was confined to the late afternoon and evening and the screens were removed half-an-hour after sunset. Each screen consisted of a wood frame covered with roofing felt and of size sufficient to span two plants. The forcing influence of these screens is noticed in the haulm growth (3rd May and $15^{\text {th }}$ June) but this effect was not reflected in the mean stolon length. From this it appears that stolon length is a character strongly influenced by day length and less so by the other environmental factors to which the haulm may be subjected.

\section{EVIDENCE FROM GRAFTING}

In view of the uncertainty attached to the results of scoring progeny for the bolter reaction, it has been necessary to adopt an indirect approach to the problem of the nature of the change normal to bolter.

To throw light on the mechanism by which the apparently discrete change affected, in a pleiotropic manner, numerous characters in the plant, the following grafting experiments were made.

At the beginning of March 1949 six normal (N) and six bolter (B) tubers of virus-free stock seed of the variety Gladstone $\left(E_{2}\right)$, selected for evenness of size, were halved longitudinally and the halves planted rose-end uppermost in pots in the greenhouse. When the leading shoots were approximately $20 \mathrm{~cm}$. tall, they were reduced to one 
per plant, the one chosen being as near to the rose end as possible. The plants were then placed in sets of 4 , each set consisting of the two halves of a normal tuber and the two halves of a bolter tuber. The shoots were then intergrafted as shown in fig. 5 .

The two self-grafted halves $\left(\frac{N}{N}\right.$ and $\left.\frac{B}{B}\right)$ then provided controls for each normal and bolter tuber, variation due to grafting being equated by the self grafting of these control pieces. The choice of sprouts from tubers of similar size and from similar positions reduced variation in vigour of the sprout due to differences in the physiological background.

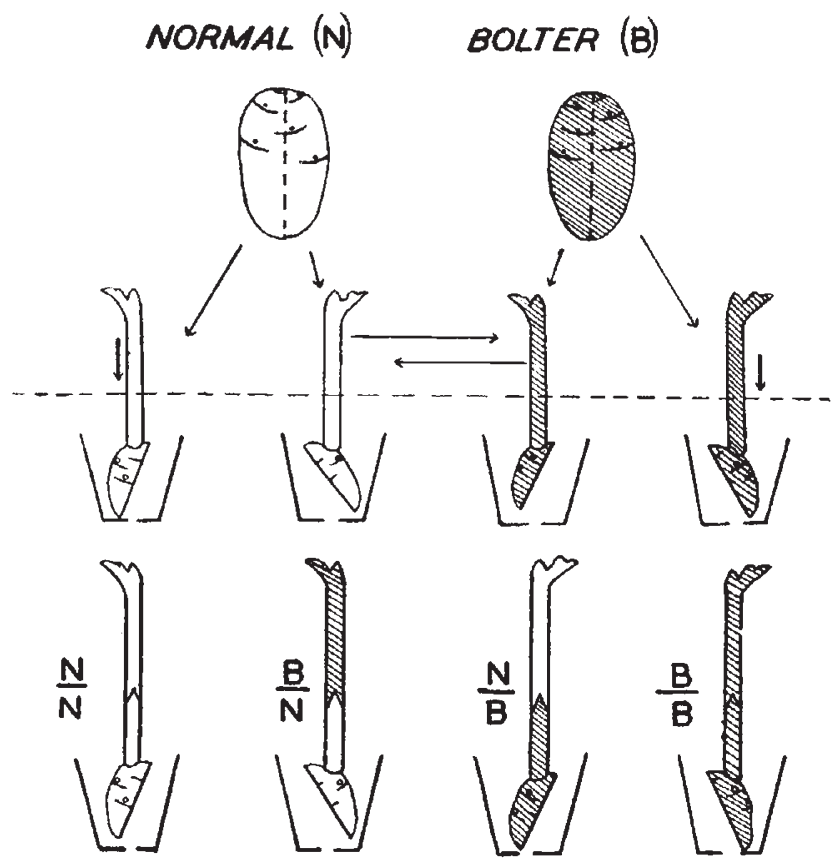

FrG. 5.-Diagram showing the method of cross grafting using sprouts from half tubers as controls. Control halves were self grafted to make any effect due to grafting a property of the whole series.

The plants were grown on in ten-inch pots in the greenhouse until the end of May and were then planted in a single row $90 \mathrm{~cm}$. apart in the row, on low hills (to aid excavation). At all times the graft union was kept above soil level and the only haulm allowed to develop was that from the original scion. The plants were lifted in mid-July and the observations are summarised in table 2.

The act of grafting reduces tuber development and the yields are therefore small compared with field grown plants. The figures are the means of observation of five of the original six sets. Data from one set was discarded on the evidence of abnormal behaviour of the $\frac{B}{\mathbf{B}}$ control plant of this set, which behaved as if it were a normal plant. 
This indicated that the original supposedly bolter tuber was in fact normal and invalidated the results from this set of 4 plants.

As a general conclusion it may be seen that the scion is the more important factor in defining the type of plant which shall develop. This is shown by the figures for tubering efficiency ( $\left.\frac{\text { weight of tubers }}{\text { weight of top }}\right)$,

TABLE 2

Summary of data on grafted plants. Variety Gladstone

\begin{tabular}{|c|c|c|c|c|c|c|}
\hline Condition $\left\{\frac{\text { Scion }}{\text { Stock }}\right.$ & $\begin{array}{l}\text { Normal } \\
\text { Normal }\end{array}$ & $\frac{\text { Normal }}{\text { Bolter }}$ & $\frac{\text { Bolter }}{\text { Normal }}$ & $\frac{\text { Bolter }}{\overline{\text { Bolter }}}$ & $\mid \begin{array}{c}\text { Standard } \\
\text { Error } \\
\text { of mean }\end{array}$ & $\mathrm{P}^{*}$ \\
\hline $\begin{array}{l}\text { Mean tuber yield per plant in } \\
\text { gms. }\end{array}$ & 226 & 266 & 102 & I $8 \mathrm{I}$ & $60 \cdot 5$ & $0 \cdot 20$ \\
\hline $\begin{array}{l}\text { Mean number of tubers over } \\
\text { Io gms. weight }\end{array}$ & $10 \cdot 3$ & 10.8 & $5 \cdot 3$ & 16.0 & $I \cdot 2 I$ & $0 \cdot 20$ \\
\hline Mean stolon length in cms. . & $10 \cdot 7$ & $9 \cdot \mathbf{I}$ & IO 1 & $22 \cdot I$ & $o \cdot 96$ & 0.05 \\
\hline $\begin{array}{l}\text { Tubering efficiency: Mean } \\
\text { tuber } \text { toight } \times \text { roo }\end{array}$ & 10.8 & 14.8 & $x \cdot 6$ & 4.4 & $4: 5$ & 0.05 \\
\hline $\begin{array}{l}\text { Mean number of open flowers } \\
\text { per plant (two observations) }\end{array}$ & $2 \cdot 3$ & $0 \cdot 8$ & $9 \cdot 3$ & $12 \cdot 4$ & $2 \cdot 64$ & 0.05 \\
\hline
\end{tabular}

Mean $=$ Mean of 5 replicates.

$\mathbf{P}^{*}=$ The value of the probability that the variation due to treatment is greater than the variation due to error.

the weight of top compared with the weight of tubers being very large with bolter scions. This conclusion is also true of tuber yield and freedom of flowering. The low yield of the $\frac{B}{N}$ combination is attributable to the lower vigour of the normal stock, relative to the bolter, coupled with the low tubering efficiency of the bolter scion. However, the figures for stolon length indicate that in all combinations in which the normal condition is present, $\left(\frac{N}{N}, \frac{N}{B}, \frac{B}{N}\right)$ the stolons are short. The short stolon condition of the normal does not appear to be altered with the bolter as scion, but the normal scion can affect the stolons of the bolter stock.

Before proceeding to the genetical results two experiments will be mentioned although they both yielded negative results.

\section{Graft transmission of a virus-like particle}

Of the tests for the presence of viruses, that of transmission by grafting is considered most conclusive (Bawden, I943, p. 53). No evidence for such transmission of bolting has, however, been obtained by the author although some four hundred of the daughter tubers of $\frac{B}{N}$ grafts have been grown on for observation at various times. 
Time of tuber development.-To test the possibility that the time of tuber initiation and the position of the tuber on the parent plant might influence the behaviour of the plant arising from the daughter tuber, approximately 1300 tubers were grown from 80 mapped plants. Three varieties, Arran Pilot $\left(E_{1}\right)$, Gladstone $\left(E_{2}\right)$ and Doone Star $\left(E_{2}\right)$ were used for this purpose. Seven abnormal plants arose from this series and were identified as bolters (B). There was, however, no correlation between the appearance of these bolters and the length of stolon, tuber weight, or time of development (assessed as height up the stem of the point from which the stolon arose).

\section{BREEDING RESULTS}

Breeding results are summarised in fig. 6. This figure shows the frequency of bolters (B) from crosses using normal (N) and bolter (B) parents. The normal maturity classification of the parents is shown. To relate the families, those of common parentage are joined by dotted lines. The slope of the lines so produced is thus a function of the condition of the two parents, that is whether they are normal $\mathrm{N}$ or bolter $\mathrm{B}$. Along the abscissa are marked points of varying amounts of bolter expression in the parentage. The order is arbitrary, but it has been chosen to show that the bolter used as male parent produce more bolters in the progeny than when used as female parent (M.M.Lines). The data on which the M.M. 1946 line is based was kindly supplied by $\mathrm{Mr} \mathrm{S}$. H. Revell, my predecessor in this work. This is the mean of scorings made from tubers of families, sown in the previous year, 1945. Replicates of each seedling were grown at Merton lat. $51^{\circ} 25^{\prime}$ (John Innes Horticultural Institution) and Edinburgh lat. $55^{\circ} 5 \mathrm{I}^{\prime}$ (East of Scotland College of Agriculture). Mr Revell found that his scoring for degree of bolting when using the character leaflet size, flower number, maturity, vigour, length of stolon and type of tuber was the same at the two centres. The other values on fig. 5 have been compiled from the author's data on scorings made in $194^{8}$ at Bayfordbury lat. $5^{1^{\circ}} 47^{\prime}$ (John Innes Horticultural Institution). The characters used were earliness of maturity (E), amount of flowering, stolon formation (the classification of Driver and Hawkes (1943) being used as a basis) and tubering, using the $\frac{\text { tuber weight }}{\text { top weight }}$ formula as in section 3 .

Method of scoring.-From the evidence of previous results in this paper, on the influence of environment on the appearance of bolters and normals, it is clear that it is difficult to produce a satisfactory definition of a bolter (B) for scoring purposes. Carson and Howard ( 1944 ) classified the progeny from their potato crosses on the following basis, cultivated, somewhat wild, wild, and very wild. The wildness referred to is a generalisation for the appearance of short-day adapted species when grown under long-day conditions. It is based on the 
rankness of haulm growth, amount of flowering, leaflet formation (variation in leaflet-formation is described in detail by Salaman, 1946), date of maturity, stolon and tuber formation. Driver and

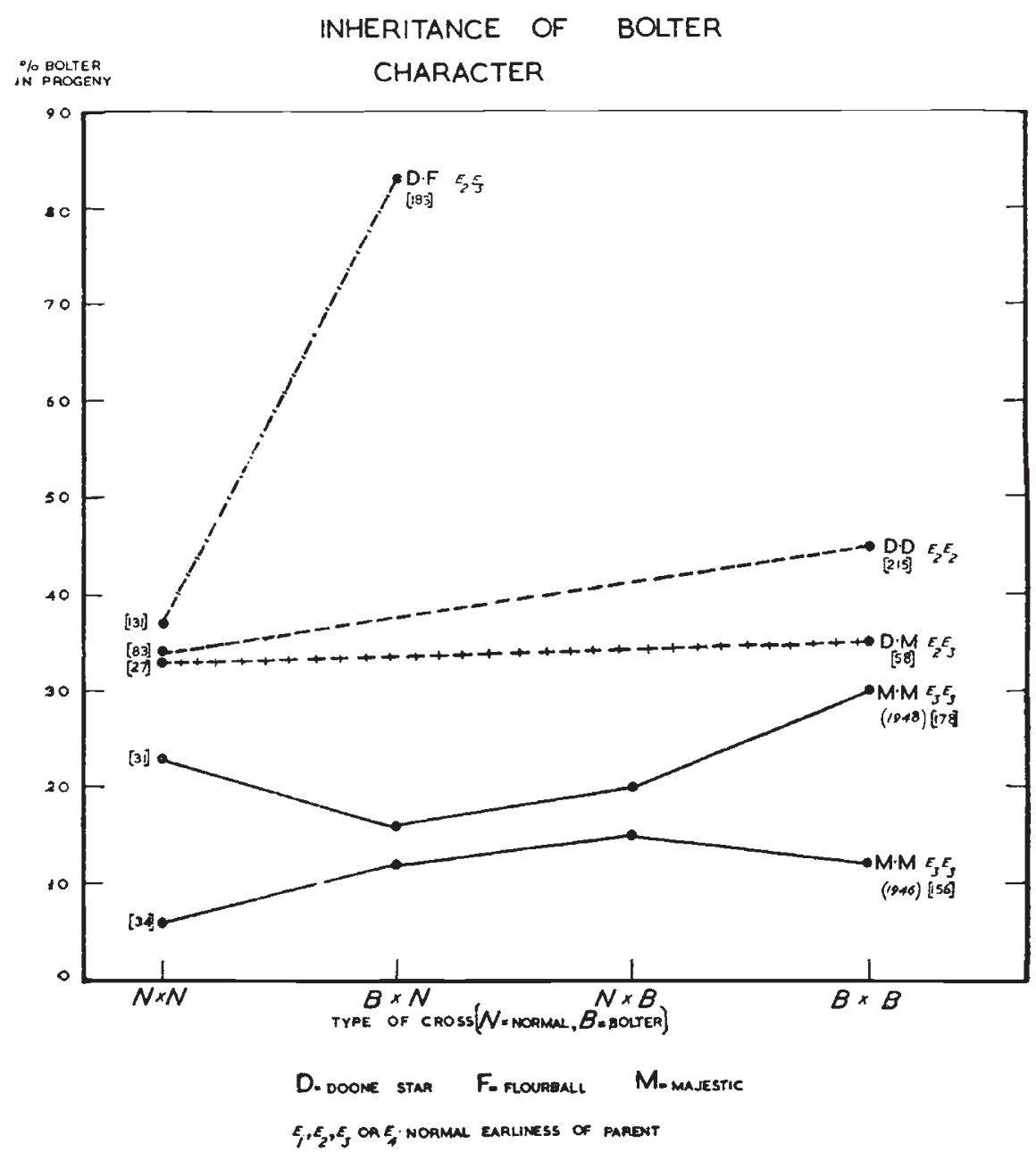

Frc. 6.-Frequency of bolters (B) in the four possible types derived from the normal (N) and bolter (B) condition of the parents. Each spot indicates the frequency of bolters from a particular family and families of common parentage are joined by a dotted line to indicate the change in percentage bolters with varying conditions of the parents. Figures in square brackets show family size.

Hawkes (1943), classify the underground parts of potato species into seven categories according to the length and number of the stolons.

In practice, the variation between trained observers is not as wide as appears possible from the complexity of the scoring methods used. Common to all the methods, is the division of the families into four groups, one of normal or cultivated types, and three of varying degrees 
of bolting or wildness. It is in the partitioning between these last three groups that the variation occurs. The modified scoring method of the author was an attempt to reduce the subjective error by the use of the two statistics, $\frac{\text { tuber weight }}{\text { top weight }}$ and mean stolon length.

\section{Conclusions}

The features of fig. 5 may be summarised as follows :-

( 1 ) Bolting appears in up to 37 per cent. of the progeny of $\mathrm{N} \times \mathrm{N}$ families.

(2) The influence of the condition of the parent plants (whether $\mathrm{N}$ or $\mathrm{B})$ is small with the exception of the Doone $\operatorname{Star}\left(\mathrm{E}_{2}\right)$ $\times$ Flourball $\left(E_{3}\right)$ (D.F.) crosses.

(3) The influence of the variety is highly significant.

(4) The influence of the time of maturity (value of $\mathrm{E}$ ) of the parents, is significant. It is understandable that varieties of maturity $E_{3}$ or $E_{4}$ should fail to give many bolters since they already possess the principle character which distinguishes bolters from normals, that is delayed maturity.

(5) The effect of the variety Flourball $\left(E_{3}\right)$ is noteworthy for the high percentage of bolters in its progeny.

\section{DISCUSSION}

The problem of bolting in potatoes may be analysed as follows :-

(I) Is it a physiological change?

(2) Is it a virus?

(3) Is the change (a) cytoplasmic, either in quality or quantity? (b) Nuclear?

(4) Is it a mutation (gene mutation or chromosomal change)?

Physiological changes.-The discreteness of the difference between the normal (N) and bolter (B) conditions makes the suggestion improbable that the change normal-bolter is due to the accumulation of a tuber constituent beyond a certain threshold value. That mechanisms of this type exist in the potato has been demonstrated by Howard (1949). He found that the tubering ability of Solanum demissum (a short-day species) was increased where the parent plant used for the production of seed tubers had been top grafted with a long-day adapted variety of Solanum tuberosum (var. Epicure $\mathbf{E}_{2}$ ). However, the negative result from the mapped plants experiment, section 3, and the relative constancy of the difference in other experiments rules out such a mechanism for bolting. The suggestion that it is a virus, may be discarded on the negative evidence from grafting and the positive evidence from inheritance studies. 
Plate I

I

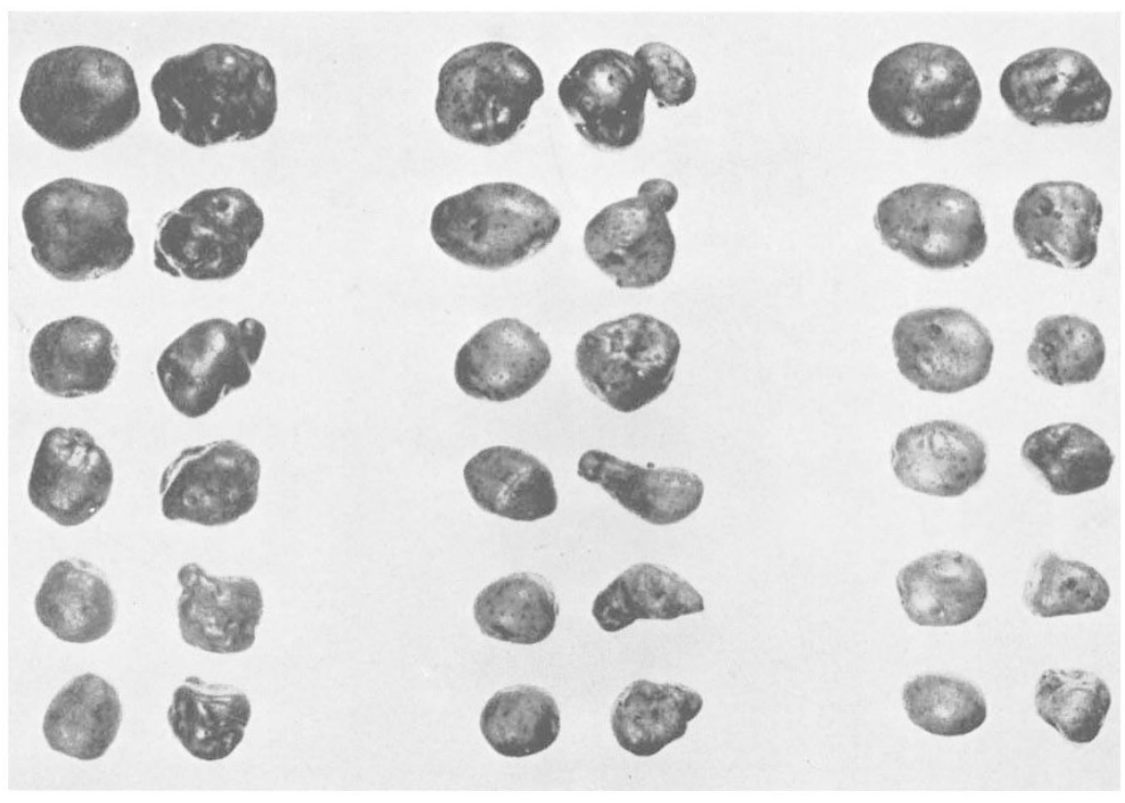

Selected tubers of three varieties from adjacent plots: I Edzcll Blue, II Gladstone, III Doone Star, showing the difference between Normal N. (left) and Bolter B. (right). 
Genetical evidence.-Until the effect of the photoperiod, in altering a number of morphological characters of the plant simultaneously, was seen to be involved in the normal-bolter change, the pleiotropic effect of this change was difficult to explain. However, it is now clear that this change might be under the control of one or more characters for photoperiodic response and the grafting experiments, section 3, demonstrates how bolter genes may operate.

The normal-bolter change therefore appears to be a nuclear or cytoplasmic mutation. Thomas ( I945) showed that an extra fragment was present on a chromosome of the bolter (B) plants. Such a fragment would explain the simultaneous change in a number of characters, but it has already been shown that this change can be produced satisfactorily by a photoperiodic change and it is therefore unnecessary to produce a fragment of a constitution identical with that of the photoperiodically changing characters. Further, Revel (unpublished) has failed to confirm the presence of these fragments.

The problem is therefore narrowed to a decision of whether the mutation is nuclear or cytoplasmic and whether the gene or genes involved are separated from, or part of, the complex of genes associated with photoperiodic response in the Tuberarium section of the genus Solanum. Driver and Hawkes, (1943), review the work on inheritance of photoperiodic response in potato species and varieties and conclude that there seem to be a large number of genes involved, giving a wide range of photoperiodic reaction.)

It is impossible to state conclusively whether the inheritance is nuclear or cytoplasmic from the breeding work to date, but it resembles the problem of rogue peas (Bateson and Pellew, 1920) and rogue tomatoes (Huskins and Crane, I930 ; Lewis, 1948, 1950).

(I) The bolter and rogue conditions all have a number of characters changed in the mutation normal to rogue.

(2) The frequency with which rogues arise germinally and bolters arise vegetatively is high. They differ in that :-

(3) Rogue peas and tomatoes arise only from seed and bolter potatoes arise vegetatively.

(4) The cytoplasmic inheritance shown in rogue peas and tomatoes by $(a)$ the variation in the percentage rogue-progeny according to the position of the flower truss and $(b)$ by the difference in frequency between normal and rogue and rogue and normal crosses in the percentage rogue progeny, is not apparent in the bolter problem.

(5) In rogue tomatoes the external condition, particularly temperature, during the early stages of growth, influence greatly the percentage of seedlings which develop into rogues.

The bolter condition appears, as far as evidence is available, stable in the vegetative tissue. No information is available in the bolter (B) $\rightarrow$ normal (N) mutation and the author has no definite observation on this point although he has noted the forward mutation (section 3). 
The obscurity of the inheritance of bolters seems, therefore, to be due to a different mechanism from that in tomatoes and peas.

\section{SUMMARY}

I. Bolters occur in early varieties of potatoes as vegetative mutations to later tuber formation and abundant flowering.

2. Bolters remain later than normals when planted over the whole period from February to July.

3. The phenotype of bolters, as measured by stolon length, haulm growth and tuber weight, can be changed to that of a normal by restricting the length of day in summer.

4. Grafting shows that the scion determines the bolting behaviour rather than the stock. There is no graft transmission of a cytoplasmic determinant.

5. Each variety has a characteristic frequency of mutation, under given conditions, and there is a range in the degree of lateness of the bolters produced.

6. Breeding results show that the frequency of bolting in the progeny depends more on the variety than on the state, bolter or normal, of the parents.

Conclusion.-In its origin and determination, bolting differs from any known type of nuclear and cytoplasmic inheritance.

\section{REFERENCES}

Anderson, T. 1925. Bolters and wildings. Board Agric. Scot., pub. 5, p. 43.

Bateson, W., AND pellew, c. 1920. The genetics of "rogues" among culinary peas (Pisum Sativum). P.R.S., B, 9I, I 86-195.

BAWDEN, F. C. 1943. Plant Viruses and Virus Diseases. Massachussetts : Chron. Bot.

CARSON, G. P., AND HOWARD, H. W. I944. Inheritance of the "bolter" condition in the potato. Nature, 154 $_{54}$ 829-830.

Davidson, w. D. 1937. Potato Growing for Seed Purposes. Dublin : Stat. Office.

DRIVER, C. M., AND HAWKes, J. G. I 943 . Photoperiodism in the potato. Imp. Agric. Bureau Pub.

Folsom, D. 1927. Virus diseases of the potato. 17 Ann. Rep. Quebec Soc. Protection of Plants, i 925-26, pp. 14-29.

hacisBarth, J. 1935. Versuche über Photoperiodismus bei südamerrkanischen Kartoffelklonen. Züchter, 7, 95-104.

hansen, H. P. 1936. Studier over Kartoffelviroser i Danmark. Tidsskr. Planteavl., $42,64 \mathrm{I}-68 \mathrm{I}$.

HAWKES, J. G. I 947. The photoperiodic reaction of potato bolters. Emp. J. Exp. Agric., 15, $216-226$.

HOWARD, II. W. I949. Potato grafting experiments. I. The effect of grafting scions of Epicure on the short-day species Solanum Demissum. J. Genet., 49, $235-241$.

HUSKINS, C. L., AND CRANE, M. B. I930. The genetics and cytology of "rogues" in tomato, an ever-sporting character. P. Int. Bot. C. (5), Cambridge.

LEwis, D. 1948. John Innes Hort. Inst. Ann. Rept. for 1947, pp. 6-8.

LEWIs, D. I950. John Innes Hort. Inst. Ann. Rept. for 1949, pp. I I-I 2. 
M'INTOSh, T. P. I931. Potato virus diseases. Scot. 7. Agric., 14, 86-88.

MURPHY, P. A., AND MCKAY, R. 1932. A comparison of European and American virus diseases of potato. P.R.S. Dublin, 20, 347-358.

REVELl, s. H. I947. Fohn Innes Hort. Inst. Ann. Rept. for 1946, p. 9.

Salaman, R. N. I926. Potato Varieties. Cambridge : University Press.

SALAMAN, R. N. I946. The early European potato: its character and place of origin. F. Linn. Soc., 53, 1-27.

THomas, P. T. 1945. Bolters in potatoes. Nature, 155, 242.

YARWOOD, C. E. 1946. Increased yield and disease resistance of "Giant Hill" potatoes. Amer. Pot. F., 23, 352-369.

Maintenance of Pure and Vigorous Stocks of the Potato. 1944. (Revised ed.) Edinburgh : Scottish Department of Agriculture. 